\title{
"Batting the Piñata and Swallowing Camels": Teachers Learn to PBLA in the Absence of Dialogic Interaction
}

\section{Yuliya Desyatova}

This article analyzes teacher professional development (PD) mandated by the implementation of portfolio-based language assessment (PBLA) in governmentfunded adult language learning programs in Canada. Through the lens of conceptualizations of teacher learning (TL), the study examined PBLA teacher-training materials, 247 teacher surveys, and participant interviews pertaining to two contrasting cases. The analysis of teacher experiences in PBLA PD revealed limited theoretical and empirical connections to recent developments in second language teacher education (SLTE). While current SLTE research emphasizes self-directed $T L$, the PBLA train-the-trainer model demonstrates top-down knowledge transmission with a potentially undermining evaluative component. The hierarchical transmission of knowledge created for teachers without opportunities for knowledge building by teachers contradicts current understandings of TL as a complex sociocultural activity. Limited effectiveness of PBLA as a TL experience may be further diminished by its potential use for punitive surveillance, as demonstrated in the extreme case analysis. As a result of this study, Richards and Farrell's conceptualizations of TL were complemented with an additional perspective informed by sociocultural theory - TL as dialogic interaction. The disconnect of PBLA vision and practice from current SLTE requires further research and attention from policymakers.

Cet article analyse le perfectionnement professionnel (PP) des enseignants tel que mandaté par la mise en œuvre de l'évaluation linguistique basée sur le portfolio (ELBP) dans le contexte des cours de langue pour adultes financés par le gouvernement du Canada. À la lumière des conceptualisations de Richards et Farrell en matière de formation des enseignants, l'étude analyse le matériel de formation des enseignants de l'ELBP ainsi que 247 sondages d'enseignants et des entrevues de participants portant sur deux études de cas contrastantes. L'analyse des expériences des enseignants dans le domaine du PP en lien avec l'ELBP a révélé une pénurie de liens théoriques et empiriques avec les développements récents dans le domaine de la formation des enseignants en anglais langue seconde (SLTE). Alors que les recherches actuelles en matière de SLTE mettent l'accent sur le PP autogéré, le modèle the formation des formateurs de l'ELBP se caractérise par une approche descendante de la transmission du savoir accompagnée d'une composante d'évaluation potentiellement affaiblissante. La transmission hiérarchique du savoir créé pour des enseignants qui n'ont pas de possibilités d'accumuler 
eux-mêmes des connaissances contredit les conceptions actuelles du PP comme activité socioculturelle complexe. L'efficacité limitée de l'ELBP comme expérience de PP pourra se voir réduire encore davantage par l'utilisation potentielle de surveillance à des fins punitives, tel que le démontre l'analyse de cas extrêmes. À la suite de cette étude, les conceptualisations de PP de Richards et Farrell ont acquis une nouvelle dimension inspirée par la théorie socioculturelle-le PP comme interaction dialogique. L'écart entre la vision et la pratique en ELBP dans le domaine de la formation des enseignants en anglais langue seconde exige des études plus poussées et doit attirer l'attention des décideurs politiques.

KEYWORDS: LINC, ESL, PBLA, portfolio assessment, teacher learning (TL), professional development (PD), language teaching, dialogic interaction

The mandatory implementation of portfolio-based language assessment (PBLA) in Language Instruction for Newcomers to Canada (LINC) and English as a second language (ESL) programs deserves a thorough examination due to limited academic literature on the topic, as well as ongoing challenges (Fox \& Fraser, 2012; Ripley, 2012, 2018; Mohammadian, 2016). In this article, the abbreviation PBLA is used as a proper noun defining the particular use of portfolios for language assessment as implemented in government-funded language programs for adult newcomers in Canada (Centre for Canadian Language Benchmarks [CCLB], 2017a). Since 2014, PBLA has become "the authorized assessment protocol" (Pettis, 2015) for approximately 2,500 teachers (Holmes, 2015) who have completed mandatory PBLA PD. This article examines PBLA PD as an opportunity for teacher learning (TL).

A comprehensive theoretical framework of TL is still a mission inaccompli (Cochran-Smith \& Zeichner, 2005; Cross, 2010). For this analysis of TL vision and experiences, the four perspectives on TL suggested by Richards and Farrell (2005) were employed: (a) TL as skill learning, (b) TL as a cognitive process, (c) TL as personal construction, (d) TL as reflective practice (p. 7). However, the review of current academic literature and the empirical data on TL in PBLA revealed the need for complementing these four conceptualizations with an additional perspective, grounded in sociocultural theory. Below, I will review the four conceptualizations by Richards and Farrell (2005), and trace them in PBLA materials and teacher experiences in PBLAmandated PD. I will conclude by proposing a fifth conceptualization of TL $T L$ as dialogic interaction - which may lead to a comprehensive typology of approaches to language TL, as well as explain the revealed inadequacy of TL opportunities in PBLA implementation. 


\section{Conceptualizing Teacher PD: Teacher Training versus Teacher Learning}

Over the last decades, understanding of TL has shifted from seeing teachers as consumers of knowledge created by other agents (linguists, researchers, teacher educators, administrators, policymakers) to acknowledging teacher knowledge-generating capacity, emerging in response to teaching and learning needs in their local contexts. This shift is omnipresent-from certain word choices in research, policy, and practice, to PD activities that teachers engage in, and theoretical frameworks employed by academics. At the level of terminology, this shift is evident in the distinction between teacher training versus teacher education (Crandall \& Christison, 2016; Richards, 2008), or teacher professional development (PD) versus professional learning (Loughran, 2006). Such changes reflect current understanding of TL as self-directed participation of teachers as knowledgeable actors rather than passive knowledge receivers, as well as potential variability of individual TL goals and outcomes. At the level of teaching and leadership practice, the shift is manifested in the move from the traditional workshop delivery model of teacher PD toward professional learning communities (PLCs), team-teaching (Richards \& Farrell, 2005), teacher research, and action research (Borg \& Sanchez, 2015). On the theoretical level, behaviourist and cognitivist perspectives on learning shifted toward more holistic sociocultural views of both learners and teachers as agents embedded in their rich local contexts (Faez, 2011; Freeman \& Johnson, 1998; Johnson, 2009; Lantolf \& Poehner, 2014; Swain, Kinnear, \& Steinman, 2011). Even though this study focuses on practice-relevant analysis, I will include a brief summary of major theories of learning, because the summary will facilitate further theoretical and empirical examination of TL experiences in PBLA.

\section{Major Theories of Learning}

The four conceptualizations of language TL offered by Richards and Farrell (2005) can be connected to three major orientations in educational psychology of the 20th century: behaviourism, cognitivism, and constructivism.

\section{Behaviourism}

Behaviourism is one of the earliest theories of human learning, which originated in stimulus-reflex studies on animals and defined learning as habit formation. One of its core premises is conditioning the subject toward desirable behaviours through repeated reinforcement. Positive reinforcement stimulates desirable behaviours through an external motivator, while negative reinforcement presumably eliminates undesirable behaviours through punishment. In language teaching, these assumptions may be traced in the audiolingual method of instruction with its focus on repetitive listen-and-repeat 
drills, conditioning learners to imitate native speakers "correctly." In teacher education, such an approach would see teaching as a sequence of behaviours that can be "learned" through observations and repetitive practice with external reinforcement. According to Ornstein and Hunkins (2017), "behaviourism still has a major impact on education," and "includes careful analysis and sequencing of learners' needs and behaviours. Principles of testing, monitoring, drilling, and feedback are characteristic" (p. 101). The limited nature of this understanding of human learning, together with advances in psychology and artificial intelligence, led to the rise of cognitivism in the middle of the 20th century.

\section{Cognitivism}

Contrary to viewing learning as acquisition of behaviours, cognitivism (from Latin cognoscere - to know) stresses the role of internal mental processes, which may not be manifested in observable behaviours. Cognitivist scientists attempt to describe sequences of internal processes leading to productive learning. When applied to language teaching, such studies continue to offer insights into how instructional strategies (e.g., explicit explanations) may support cognitive processing and facilitate language learning (Han \& Rast, 2014; VanPatten \& Cadierno, 1993). When applied to teacher education, cognitive approach would focus on teachers' "growth in cognitive structures" (Hennissen, Beckers, \& Moerkerke, 2017), "cognitive performance" (Kozulin, 2015), conceptual knowledge, and improved linking between practice and theory. Good teaching practice can presumably be derived from theory; therefore, the goal of teacher education is to facilitate deep conceptual understandings and their translation into theoretically informed practice. The major shortcoming of both behavioural and cognitive approaches is the neglect of learner agency and the impact of sociocultural environments as contributors to the learning process.

\section{Constructivism}

Constructivism is an umbrella term covering a range of approaches that emphasizes the previously unacknowledged role of learner agency, as well as the interactive dimension of knowledge (co-)creation and development: "the learner is the key player; learners participate in generating meaning or understanding. The learner cannot passively accept information by mimicking others' wordings or conclusions. Rather, the learner must internalize and reshape or transform the information" (Ornstein \& Hunkins, 2017, p. 113). Knowledge transfer can be facilitated, impeded, or modified by teacher learners, depending on individual, group, and contextual factors. These factors may include how applicable teachers perceive a theory to be for their class;

what resources are available to teachers for enacting the suggested practice improvement; how the students respond to attempted changes in practice. 
According to constructivist approaches, knowledge cannot be transmitted, but needs to be actively constructed and reconstructed by the teacher learner interacting with the context in multiple dimensions: cognitive, affective, material, cultural, and political.

While elements of all these three meta-theories can be traced in current practices, curriculum documents, and teacher and learner beliefs, the general tendency in current research has been toward acknowledging the complexity and the constructed nature of learning processes, rather than limiting learning to cognitive-behavioural domains (Illeris, 2018).

\section{The Four Conceptualizations of TL}

Richards and Farrell's (2005) conceptualizations of TL can be productively examined alongside the major educational theories: TL as skill learning aligns with behaviourism, TL as a cognitive process aligns with cognitivism, and $T L$ as personal construction together with $T L$ as personal reflection represent a constructivist understanding, even though contextual factors are not emphasized. This alignment may be helpful in uncovering key assumptions behind the four conceptualizations, such as perspectives on the expected teacher role(s), the nature of TL and language teaching, and the central locus of both processes. These assumptions may remain unexamined yet influential in achieving the projected outcomes of a PD activity.

In a comprehensive investigation of individual TL paths, Kubanyiova (2012) identified teachers' "ideal selves" as "central cognitions of conceptual change" (p. 101), on which a teacher's response to a TL experience may depend. If the "ideal self" of a teacher-researcher matches the expected role in the TL experience, it may be taken on enthusiastically. On the contrary, if there is a significant dissonance between the two roles, the TL experience may have little impact, perceived as a burden, or rejected by the teacher. For instance, if teachers are expected to be knowledge creators through action research, but they envision themselves as acquirers of best practices, the tension between the two visions may fail to produce successful outcomes in a PD initiative attempting to enact a cognitive or constructivist conceptualization of TL. Vice versa, if teachers see themselves as active knowledge creators in and for their class but are expected to become skill acquirers of best practices designed outside of their classrooms, a similar tension may jeopardize achievement of the desired outcomes envisioned from the TL as skill learning perspective. Arguably, the larger the gap between expected and desired teacher roles, the more untenable tensions may arise for individual teachers, organizations, or education systems. Therefore, understanding how teacher roles envisioned in PBLA teacher training may support or conflict with the "ideal self" envisioned by LINC/ESL teachers may assist in clarifying PBLA potential for effectiveness as a PD initiative. Currently, nega- 
tive teacher response is interpreted as "resistance to change" (CCLB, 2017e), which dismisses the issue rather than addressing it.

To elaborate on how the unexamined tensions between policy-expected and teacher-desired roles can be traced, common PD activities can be juxtaposed with the four conceptualizations of TL (Richards \& Farrell, 2005). However, these four conceptualizations do not allow for inclusion of such TL activities as action research, critical friendship, mentoring, peer observations, peer coaching, and PLCs. Promising to address limitations and challenges of less interactive PD activities, these TL opportunities involve multiple agents, depend on mutual participation, and reach beyond the last two conceptualizations of TL as personal construction or personal reflection. To include these interactive activities, a new conceptualization of TL needs to be created, which would reflect the multidirectional nature of interaction in a community of practice $(\mathrm{CoP})$. My goal was to name this additional conceptualization after reviewing the literature and the empirical data on TL in PBLA.

\section{Preparing Teachers for PBLA Implementation}

PBLA continues to raise questions about its explicit and implicit goals (Vanderveen, 2018). However, after pilots in a number of service provider organizations (SPOs) in 2011-2012 (Pettis, 2015), mandatory national PBLA implementation started in 2014, despite numerous concerns documented in the few studies of those initial pilots (Fox \& Fraser, 2012; Ripley, 2012). Between 2014 and 2017, at all SPOs across Canada, a series of PBLA teachertraining workshops were delivered by designated PBLA Lead Teachers/ Leads, who themselves had undergone rigorous training. Leads were expected to support PBLA implementation in their organizations, and were provided with teacher-training materials, including scripted PowerPoint presentations and handouts (CCLB E-learning, n.d.), which might have been an attempt to mitigate well-documented challenges of cascade PD models (Turner, Brownhill, \& Wilson, 2017).

The PBLA teacher training was both intensive and extensive. The first series of PD days took place over 5 months, and a series of follow-up workshops were expected "to support the PBLA community of practice" (CCLB E-learning, n.d.). The training started with an introduction to theory behind PBLA and progressed to practice-oriented sessions on module planning, task design, and "introducing PBLA protocol" (CCLB, 2015, pp. 1-2). As an outcome of this training, each LINC/ESL teacher in Canada is required to design or find, administer, mark, provide action-oriented feedback, and a reflection opportunity for their students on at least 8 to 10 assessment artefacts per skill area (listening, speaking, reading, and writing) "per reporting period" (CCLB, 2017c). This requirement of 32 assessment artefacts as a minimum evidence of students' readiness for the next CLB is identical across language learning levels, frequency and intensity of the class/program, teacher experi- 
ence, or other factors, which may indicate an underestimate of the variety of individual, classroom, and institutional ecologies.

For multilevel classes, assessment instruments are expected to be tailored to individual student benchmark in the respective skill, which increases the original number of 32 required assessment artefacts to be prepared by the teacher. Furthermore, because many LINC/ESL teachers have part-time job assignments with different classes and even organizations (Valeo \& Faez, 2013), the number of mandatory assessments may have to be further multiplied, depending on the employment situation of the teacher. This dramatic increase in workload required by PBLA has been an ongoing concern for teachers, administrators, and researchers since the first studies of original pilots (Fox \& Frazer, 2012; Ripley, 2012; Mohammadian, 2016), but has received limited attention from policymakers or funders as of the end of 2018. The abundance of teacher concerns over PBLA and its implementation, as well as an ongoing absence of productive response, culminated in an online petition: "Stop PBLA ...," started by an Ontario teacher (Lachini, 2017). The petition collected more than 500 signatures within a few weeks, but it was unclear if it reached its target audience of decision-makers.

Most available studies investigated PBLA from the perspective of implementation benefits and challenges (Fox \& Frazer, 2012; Fox, 2014; Ripley, 2012, 2018). Despite multiple challenges reported by teachers in their attempts to adhere to the mandatory assessment protocol, the official PBLA discourse seems to be oblivious to the gravity of the issues, and attributes them either to "growing pains" that will gradually transform into visible benefits for all stakeholders, as teachers and SPOs adjust to the new demands (CCLB, 2017d), or to "resistance to change" that should be addressed accordingly (CCLB, 2017e). The key to effective adjustment is seen in developing individual teacher skills, facilitated by mandatory PBLA PD and ongoing support from Leads. While the literature does not focus specifically on TL in PBLA, the issue of teacher skills as the key to successful PBLA implementation is a pervasive theme in the official PBLA discourse. Numerous presentations dedicated to PBLA have been delivered at local, provincial, and national conferences. To the chagrin of some teachers, the ubiquitous PBLA training significantly reduced the diversity of previously available PD options (Morrissey, 2018).

\section{Research Methods}

This study was guided by the following research questions:

Research Question 1 (RQ1): How is TL conceptualized and operationalized in PBLA teacher training? 
Research Question 2 (RQ2): How do LINC/ESL teachers describe their TL experiences in PBLA-mandated PD activities?

Research Question 3 (RQ3): How much convergence/divergence exists between the policy-articulated vision of TL and teacher perception of the TL opportunities?

Research Question 4 (RQ4): How can the conceptualizations of TL by Richards and Farrell (2005) explain the convergence/divergence?

To answer these research questions, PBLA implementation guidelines (CCLB, 2017) were examined for indications of the four theoretical conceptualizations of TL, including vocabulary choices, suggested PD activities, as well as expected teacher roles and assumptions about TL (RQ1). The findings from the official PBLA discourse were juxtaposed with teacher responses to survey and interview questions (RQ2) to establish possible congruence or lack thereof (RQ3). Finally, the theoretical lens of the four conceptualizations of TL was employed for illuminating the findings (RQ4).

The empirical data on teachers' experiences of PBLA training as a TL opportunity were drawn from the data collected for a larger $\mathrm{PhD}$ research project investigating perception of PBLA impact on teaching and learning by different groups (teachers, Leads, administrators, and learners). The large mixed-methods data set consists of Likert-type surveys $(N=323)$ and interviews $(N=68)$ collected between October 2017 and June 2018 across Canada. I developed the surveys and interview guides to elicit responses on a range of themes represented in existing PBLA literature. The thematic breadth reflected the exploratory nature of the larger research project and responded to the paucity of academic literature on PBLA. For this article, only open-ended survey responses to the 14 Likert-type statements on teacher experiences with PBLA PD (Appendix A) and interview excerpts on two contrasting cases were reported.

Open-ended survey responses were coded openly, axially, and selectively (Merriam, 2002). The coding process was an ongoing cycle of multiple revisions, especially between the open and axial levels. As a result, 174 codes were generated from the data, which, through numerous subthemes, were grouped into four major themes relevant for the current examination: Satisfied with PBLA PD (41 comments), Dissatisfied with PBLA PD (177); Mixed feelings about PBLA PD (4), and Challenges for and around PBLA Leads (123). A segment of these data with initial coding was reviewed by a graduate student from the same department to ensure transparency of analysis. In a few cases when clarification of the coding scheme was needed, collaborative coding was conducted until an agreement was reached.

Selective coding established absence/presence of connections between reported teacher experiences and the four conceptualizations of TL. An 
extreme case analysis allowed for an in-depth examination of teacher experiences. Interviews illustrating two contrasting cases of TL opportunities were transcribed by the researcher. As part of member checking, a draft of this article highlighting the sections on the relevant cases was reviewed and approved by the three participants. As an outcome of data analysis, a fifth conceptualization of TL emerged - TL as dialogic interaction - which complemented the existing typology with a perspective on TL informed by the sociocultural theory.

\section{Findings: Vision and Practice of TL in PBLA}

I will start with reporting observations on the language used in PBLA implementation guidelines. Similar vocabulary was mostly preserved in this article to reflect authentic PBLA discourse ${ }^{1}$.

\section{Teacher Training Delivery}

Such words as teacher training, delivering workshops, teacher skills are used repeatedly in PBLA materials (Pettis, 2015; CCLB, 2017). The responsibility of a Lead is "deliver workshops" using materials provided. Other responsibilities suggest dialogic engagement in the TL process: Lead Teachers are to "facilitate informal small-group discussions," "meet one-on-one with teachers to discuss PBLA-related topics" (CCLB, 2017f). However, study participants did not explicitly report such activities. On the contrary, teachers $(n=4)$ commented that when questions arose during the PD sessions, collective search for an answer within the group was not an option: "The numerous claims of research-based evidence are never discussed. We are always told not to question or complain, just do it" (Teacher 233; T233). Participants' responses illustrated the rigid hierarchy of knowledge validation and transmission with teachers being at the bottom of the pyramid. Questions were reported to be unwelcome in PBLA PD:

The sessions, although providing some helpful material, have for the most part been lecture format with power points, with little feedback asked for from the Instructors. It has been more of a "this is the way you need to do it" and when questioning methods or outcomes, the answers received have had more of the effect of attempting to shut down the questioning, rather than convincing me of the benefit.

Even though PBLA implementation materials mentioned group discussions, reports of collective meaning-making during the PD sessions were absent in the data. Presentation-style workshops with elements of group activities dominated PBLA PD and were expected to result in individual teacher skill development. 
Teachers commented on the inadequacy of such expectations, especially considering PBLA emphasis on meeting the real-life needs of newcomer learners: "I wish that these courses would model the style of teaching that they propose-use needs assessments before teachers start the course, and tailor courses to suit said needs!" (T241). The expectations of active engagement between students and teachers in PBLA contradicted the absence of similar engagement between teacher learners and Leads in PBLA PD.

\section{Leading Teacher Learning in PBLA Implementation}

In addition to workshop delivery, responsibilities of Leads also include "team-teach[ing]" and "giv[ing] demonstration lessons" (CCLB, 2017f), but this is a rare mention of a possibility for teachers to see PBLA in action. Limited empirical data are available on this kind of practical modelling. Occasionally, PBLA Leads or administrators reported sharing assessment materials they created (Administrator 11; A11). However, a significant number of teacher surveys $(n=33)$ commented on inadequate practical support offered by Leads, which teachers found to be a missing link in their PBLA training: "Where are the examples to follow? Our leads have all encompassing power to refuse our tasks but there are no models ..." (T32).

While teachers generally appreciated support from their Leads $(n=26)$, they also commented empathically on the challenges in leading PBLA teacher training $(n=39)$ : "The work is exhausting, requires an inordinate amount of time. The teaching hours are limited, the pay is ridiculous" (T175); "They [pronoun redacted] are great. It's not their fault we are frustrated" (T118). However, participants also commented on alarming trends in the train-thetrainer model: Leads' unavailability due to attrition or other reasons $(n=12)$; Leads taking on the role because they were "talked into it" (T61) or other pressures $(n=5)$; novice teachers becoming Leads due to lack of interest from experienced teachers $(n=8)$ : “They [pronoun redacted] suffer. They are overwhelmed. Not motivated at all. They were new to teaching and centre so the manager dump[ed] this on them and they were just nice and grateful to get a job. So, they were forced to do it" (T112). As a result of frequent issues around the quality of support, and Leads' availability, motivation, and retention $(n=123)$, Lead attrition further jeopardized the effectiveness of PBLA PD.

Teacher discomfort with the train-the-trainer model was frequently articulated as dissatisfaction with Leads $(n=84)$. Following the comments on inadequate support $(n=33)$, the second most frequent comment was on complicated relationships between Leads and other teachers $(n=14)$ : "There is an attack and defend relationship between the Leads and the staff" (T121). Leads themselves commented on the power imbalance and the unhealthy climate: "I feel like a cop ratting on colleagues and I feel management likes having lead teachers to provide proof they couldn't otherwise get" (T20). The 
recurring perception of PBLA as a tool for punitive surveillance raises questions about the hidden goals of PBLA implementation (Vanderveen, 2018).

\section{Role of the Teacher in PBLA Teacher Training}

As these data demonstrated, despite group activities being mentioned in workshop materials, PBLA PD relied significantly on individual teacher cognitive, interactional, and skill-acquisition labour: "I have figured out most on my own from discussion with other teachers and reading" (T233). Teachers found this expectation overwhelming: "PBLA training was basically: you're on your own. Invent modules, teaching materials, assessment materials and rubrics" (T42). This led to multiple challenges with translating PBLA theory into practice: "I felt like I was failing every step of the way without clear support on how to make a very theoretical idea work in practical terms in a real classroom" (T185). The disconnect between the theory presented and the practice expected was a frequent theme $(n=38)$ : "The irony is that the more practical PBLA claims to be, the more theoretical it is shown to be" (T18); "Lots of theory but I am not convinced. I may understand what they are trying to do but I am not convinced that it is helpful/beneficial in the long term" (T37). The theory-practice gap observed by the teachers may indicate PBLA designers' conceptualization of TL as a cognitive process, with the expectation that theories would be productively applied as individual teachers develop their conceptual understanding.

However, teachers see their practical knowledge created in the teaching process as more valid and effective than the one mandated by PBLA, thus reclaiming the value of practice-generated knowledge in response to the assigned role of knowledge receivers: "[PBLA PD was] awful and a huge waste of time that could be better spent teaching - actually teaching - which is what we love to do" (T1). The affective contrast-teaching as "what we love to do" and the PD as "awful and a huge waste of time" - may be a reaction to the perceived infringement of the mandated theory on the territory of practical teacher competence, which undermined teachers' role as capable decision-makers: "The way I interpreted the introduction of PBLA was 'forget how you taught before. This is the new way, the better way.' The transition was MASSIVE" (T51). A glaring gap is suggested between teaching pre-PBLA and the newly mandated norm. However, a significant number of teachers reported employing similar routines pre-PBLA, albeit in a more flexible format $(n=83)$ : "I used the CLBs previously and used my own rubrics - a simpler and more effective system than PBLA" (T42); "Already did learner needs assessments and task-based learning" (T168); "We were confident users of portfolio-based assessment" (T219). Even though practices required by PBLA had been part and parcel of teaching repertoire, teachers express serious concerns and poignant critique of similar mandatory requirements. This contradiction may be explained by the conflict between PBLA-mandated 
and teacher-desired roles: "I lost my interest when we were told: Teach less and assess more. Ugh ..." (T219). Teachers object to the demands to replace activities at the core of their professional identity (teaching), with activities perceived as peripheral (assessing and record-keeping): "they are forced to do something that is against their nature" (T97).

Even when participants responded to questions about the value of PBLA PD as "not sure," the experience was not described as positive: "We batted the PBLA piñata back and forth at so many meetings. We've had ardent PBLA leads and boring leads. We've discussed nitty and gritty. We have strained out gnats and swallowed camels" (T190). The metaphors regressed from repeated batting the piñata in the vain hope for a tangible reward, to swallowing a camel as an act of questionable need yet great discomfort. These vivid images of unproductive activities suggest very modest positive outcomes in return for the efforts invested in PBLA teacher training. In general, the ratio of positive to negative teacher comments on PBLA PD in these data is 1:4.5 (41:177).

\section{An Exemplary Case: Compensating for the Shortcomings of PD design}

In the available data, the only report of modelling through teaching demonstration and team-teaching was offered by an administrator who had serious concerns about the "instructional design" of PBLA PD as lacking opportunities for "knowledge sharing." This administrator (A31) exercised leadership authority by leading the demonstration parts in lessons co-taught with the teachers. Initially, offers of team-teaching from the administrator were met with "trepidation," but when the perception of this activity as an evaluation by a superior gradually changed to seeing it as an opportunity for TL, teachers became more open to, and appreciative of, the opportunity.

Even though A31 was not a Lead Teacher, the administrator felt the need to support the teachers beyond what was required in the policy, which was found lacking effective "instructional design." This support was offered through PD activities-demonstration lessons and team-teaching, which were unique in this data set. The collaborative practical guidance addressed the teaching rather than the assessment part of the complicated PBLA equation, which restored the vision of teaching as the core teacher activity. This reassertion of the primary teacher role connects to the teacher comments above, which reflected the concerns over the assessment overshadowing teaching and learning in PBLA. This exceptional case emerged in response to the need to find a more productive and practice-oriented way to support TL than the options presented in PBLA materials.

\section{An Extreme Case of Teacher Abuse for "Noncompliance" with PBLA}

In reporting their PBLA implementation experiences, participants frequently perceived their Leads and administrators as evaluators of teacher-created 
materials, without sufficient models to follow being offered or developed collaboratively: "I feel critiqued more than I feel supported" (T37). At least in the case described below, such evaluation was not limited to teacher perception, but became a punitive practice within the organization. The evaluation did not produce action-oriented feedback in the process of material design, but the verdict was delivered post-factum, during routine binder reviews by administration after the end of the term. In this organization, which I will identify as SPO X, student binders were "rejected" as "non-PBLA-compliant" after the end of the semester, when the minimum of 32 assessment tasks had been completed by the class, marked and returned by the teachers (T32, T91, and T143). This situation led to latent and escalated conflicts in SPO X, with stress leaves taken by teachers whose class binders/students were "failed." The evaluative appraisal of the end product created by individual teachers took place at the stage when no modification of, or dialogue about, teacherproduced assessment instruments was possible; the students were denied an opportunity to move to the next level due to the "failure" of teacher-created assessments:

they are failing our work. ... they are pushing things back and saying this isn't good. So, our professional judgement is undermined continually. So, we might create something and then it's given back to you as garbage, and you have to redo it. (AT32)

Another issue aggravating the situation was the fact that Lead Teachers at this SPO were lacking up-to-date classroom teaching experience and were unavailable for individual or group support before/during the process of material design, contrary to PBLA implementation guidelines.

While this case appears to be extreme and not typical, the fact that such abuse of opportunities for TL emerged and continued under the banner of PBLA compliance indicates serious flaws in the PBLA PD model and requires an adequate response from policymakers. According to the participants, during the academic year, assistance was sought on multiple occasions at various levels of decision-making, but no productive resolution ensued. Even though this extreme case represents a single SPO, it is a large organization that impacts many teachers and adult learners. The reported evaluative practices are unethical and undermining of the basic human rights for respect and fair treatment.

\section{Discussion}

In their practice-oriented guide to teacher PD, Richards and Farrell (2005) distinguished four perspectives operationalizing TL through different approaches, environments, and activities: (a) TL as skill learning, (b) TL as a cognitive process, (c) TL as personal construction, (d) TL as reflective prac- 
tice. However, these four perspectives offered moderate explanatory power in illuminating possible reasons for teacher apprehension demonstrated in/ during/after PBLA PD, or the underlying issues revealed in the two contrasting cases of PBLA implementation. Therefore, I propose an additional conceptualization - TL as dialogic interaction - which would account for recent understandings of TL as a complex sociocultural process (Cross, 2010; Faez, 2011; Johnson, 2009; Lantolf, Poehner \& Swain, 2018; Lee, Murphy, \& Baker, 2015; Richards, 2008). This perspective would acknowledge that TL is inextricably connected to factors such as personal and institutional histories and ecologies (Donato \& Davin, 2018; Johnson \& Golombek, 2018); social interactions in the workplace and beyond; the affective dimension (Veresov \& Mok, 2018) and its impact on TL. TL as a sociocultural activity is not confined to individual teacher cognition but is interactively constructed by a group of agents in a classroom, in a school, and in the larger sociopolitical context.

\section{TL as Dialogic Interaction}

The concept of a dialogue, versus unidirectional/monologic transmission of meaning, continues to play an important role in philosophy and education, from Socrates to Freire (Freire \& Macedo, 1995; Guilherme \& Morgan, 2018). Dialogue is seen as the focal component of the learning process in general (Freise, 2018; Hall, 2017; Lefstein \& Snell, 2014; Neville Rule, 2015; Sarid, 2012; Skidmore \& Murakami, 2016), language learning (Hall, Vitanova, \& Marchenkova, 2005), TL (Hennessy, 2014; Johnston, 1994; Masson, 2018; Scarino, 2014), and organization management (Bushe \& Marshak, 2015). According to Renfrew's reading of Bakhtin (2015), "Dialogism is more than a literary or a purely interpersonal phenomenon: it describes the condition of all verbal interaction and therefore of all conceptual, social and ideological activity" (p. 91). On the contrary, monologic discourse leads to lack of mutual understanding: "to some extent, primacy belongs to the response ... Understanding comes to fruition only in the response" (Bakhtin, 1975, as cited in Renfrew, 2015, p. 90). Without a response from the "other," a shared meaning of a concept may not emerge, as may be the case with PBLA implementation, where a persistent gap exists between the policymakers' and practitioners' understandings of PBLA and its impact.

When dialogic interaction is absent, mutual understanding may be lacking at various levels: between policymakers and practitioners, between administrators and teachers, or between teachers and students. At the classroom level, monologic discourse can be an interaction pattern in a teachercentred classroom, or limited to an isolated moment of classroom interaction, when ongoing dialogues with individual learners are not feasible. At the level of long-term national policy implementation, the persistence of monologic discourse and absence of shared understandings undermines the possibility of achieving PBLA goals and projected outcomes. 
Richards (2008) also asserted the crucial role of a dialogue for the emergence and sustainability of CoP: "'Learning how to talk' is essential in order to participate in a community of practice. It involves learning to share ideas with others and to listen without judgement" (p. 170). Johnston (1994) offered further elaboration on the three features of a productive dialogue in educational settings - participation, contingency, and negotiation. I believe that conceptualizing TL as dialogic interaction captures these three features: (a) active participation of all agents, (b) openness to hearing the other side and adjusting to unpredictable developments (contingency), and (c) readiness to negotiate (negotiation).

However, teacher survey responses did not offer empirical evidence for the presence of dialogic interaction in PBLA PD. This is especially problematic because teachers themselves need to be active listeners, observers, and learning partners in their classrooms (Loughran, 2006), which is an ongoing interplay of participation, contingency, and negotiation. Extending a similar understanding of learning to TL would be modelling an effective learning environment (top-down modelling), or an application of what teachers may already be doing in their classrooms to their own TL experiences (uptake of a promising teaching practice). As Johnston (1994) described it, "dialogue involves contestant negotiation. Because of its contingency, truly dialogical relations can only be maintained through a constant moving to and fro between participants in the domains both of content (what we are studying) and process (how we go about it)" (p. 158). However, in PBLA PD, teachers were denied opportunities to negotiate either the content or the process of their own learning.

Table 1

Conceptualizing Teacher Learning: A Continuum of Approaches

\begin{tabular}{|c|c|c|c|c|c|}
\hline \multirow{2}{*}{$\begin{array}{l}\text { Meta-theories of learning and } \\
\text { development }\end{array}$} & \multirow{2}{*}{$\begin{array}{l}\text { Behaviourism } \\
\text { TL as skill } \\
\text { learning }\end{array}$} & \multirow{2}{*}{$\begin{array}{l}\text { Cognitivism } \\
\text { TL as a cognitive } \\
\text { process }\end{array}$} & \multicolumn{2}{|c|}{ Constructivism } & \multirow{2}{*}{$\begin{array}{l}\text { Sociocultural theory } \\
\text { TL as dialogic } \\
\text { interaction }\end{array}$} \\
\hline & & & $\begin{array}{l}\text { TL as personal } \\
\text { construction }\end{array}$ & $\begin{array}{l}\text { TL as personal } \\
\text { reflection }\end{array}$ & \\
\hline Locus of TL & \multicolumn{4}{|c|}{ Individual teacher } & $\begin{array}{l}\text { Communities of } \\
\text { practice }\end{array}$ \\
\hline Goal of the TL process & $\begin{array}{l}\text { Acquisition of } \\
\text { skills }\end{array}$ & $\begin{array}{l}\text { Translating theory } \\
\text { into practice }\end{array}$ & \multicolumn{2}{|c|}{$\begin{array}{l}\text { Constructing a personal understanding how } \\
\text { to translate theory into practice }\end{array}$} & $\begin{array}{l}\text { Collective } \\
\text { participatory } \\
\text { theorization of } \\
\text { teacher practices } \\
\text { (praxis) }\end{array}$ \\
\hline Role of the teacher learner & $\begin{array}{l}\text { Craftsperson of } \\
\text { best practices }\end{array}$ & $\begin{array}{l}\text { Knowledge } \\
\text { acquirer and } \\
\text { applier }\end{array}$ & $\begin{array}{l}\text { Individual } \\
\text { knowledge } \\
\text { builder }\end{array}$ & Reflective practitioner & $\begin{array}{l}\text { Knowledge creator, } \\
\text { researcher, engaged } \\
\text { seeker of promising } \\
\text { solutions }\end{array}$ \\
\hline
\end{tabular}




\begin{tabular}{|c|c|c|c|c|}
\hline $\begin{array}{l}\text { Meta-theories of learning and } \\
\text { development }\end{array}$ & Behaviourism & Cognitivism & Constructivism & Sociocultural theory \\
\hline $\begin{array}{l}\text { Key assumptions about teaching } \\
\text { and } T L\end{array}$ & $\begin{array}{l}\text { Set of learnable } \\
\text { skills can be } \\
\text { transferred from } \\
\text { an expert to a } \\
\text { novice }\end{array}$ & $\begin{array}{l}\text { Body of } \\
\text { knowledge can } \\
\text { be rationally } \\
\text { analyzed and } \\
\text { applied in practice }\end{array}$ & $\begin{array}{l}\text { Individually constructed understanding } \\
\text { guided by both theory and practice }\end{array}$ & $\begin{array}{l}\text { Multiple factors } \\
\text { within and beyond an } \\
\text { individual (personal } \\
\text { histories, emotions, } \\
\text { community, } \\
\text { socioeconomic, } \\
\text { and political } \\
\text { environments) impac } \\
\text { learning, teaching, } \\
\text { and TL }\end{array}$ \\
\hline
\end{tabular}

Note. $\mathrm{TL}=$ Teacher Learning.

Table 1 summarizes the four conceptualizations of TL by Richards and Farrell (2005), complemented with the fifth one-TL as dialogic interaction. The additional conceptualization reflects the recent "sociocultural turn" in language teacher education (Johnson, 2006) and was derived from both the literature and empirical data. Table 1 aligns the five conceptualizations with major theories of learning and traces the assumptions about the goals of the TL process, its loci, expected teacher roles, as well as assumptions about the nature of TL and language teaching. To further elaborate on how these assumptions can be traced in common PD activities, Table 2 connects PD activities with the five conceptualizations. These two tables can assist in examining potential areas of tension in a PD initiative where gaps between the teacher-desired and policy-expected teacher role may jeopardize achievement of projected outcomes.

Table 2

PD Activities Reflecting the Five Conceptualizations of Teacher Learning

\begin{tabular}{|c|c|c|c|c|c|}
\hline $\begin{array}{l}\text { Conceptualization } \\
\text { of } T L\end{array}$ & TL as skill learning & $\begin{array}{l}\text { TL as a cognitive } \\
\text { process }\end{array}$ & $\begin{array}{l}\text { TL as personal } \\
\text { construction }\end{array}$ & $\begin{array}{l}\text { TL as personal } \\
\text { reflection }\end{array}$ & $\begin{array}{l}\text { TL as dialogic } \\
\text { interaction }\end{array}$ \\
\hline Typical TL activities & $\begin{array}{l}\text { Workshops and } \\
\text { presentations, expert } \\
\text { observations and } \\
\text { feedback }\end{array}$ & $\begin{array}{l}\text { Reading professional } \\
\text { and research articles, } \\
\text { action research }\end{array}$ & $\begin{array}{l}\text { Self-monitoring, self- } \\
\text { directed TL through } \\
\text { personally relevant } \\
\text { means }\end{array}$ & $\begin{array}{l}\text { Reflective journal } \\
\text { writing, introspective } \\
\text { analysis }\end{array}$ & $\begin{array}{l}\text { PLC (professional } \\
\text { learning community), } \\
\text { action research, } \\
\text { critical friendship, } \\
\text { mentoring, peer } \\
\text { observations, peer } \\
\text { coaching }\end{array}$ \\
\hline Typical vocabulary & $\begin{array}{l}\text { Language training, } \\
\text { teacher training, } \\
\text { workshop delivery, } \\
\text { best practices }\end{array}$ & \multicolumn{2}{|c|}{$\begin{array}{l}\text { Language learning, teacher learning, } \\
\text { professional development }\end{array}$} & $\begin{array}{l}\text { Reflection, reflective } \\
\text { practice, reflective } \\
\text { practitioner }\end{array}$ & $\begin{array}{l}\text { Community of } \\
\text { practice, PLC, } \\
\text { teacher support } \\
\text { groups, knowledge } \\
\text { sharing, knowledge } \\
\text { building }\end{array}$ \\
\hline
\end{tabular}

Note. $\mathrm{PD}=$ Professional Development; $\mathrm{TL}=$ Teacher Learning. 
The two tables should not be interpreted as a rigid typology that slot a PD activity into a single possible cell. The tables suggest a continuum where concrete operationalizations of the five perspectives may combine features of apparently distant conceptual understandings. For instance, peer observations can become a dialogic activity in a $\mathrm{CoP}$, as indicated in the exemplary case above, if observations lead to new understandings for both participants. However, empirical accounts of peer observations as an authentic practice of a CoP are sparse (Vásquez \& Reppen, 2007). On the contrary, observations are often enacted and perceived as evaluations, which may explain the limited uptake of this promising TL tool (Richards \& Farrell, 2005). When an observation is conducted by a superior and leads to an evaluative outcome of observable skills, the intent, atmosphere, and the impact of the event may shift toward the skill-oriented end of the continuum. Therefore, it is not the title or an official intent of a PD activity that reflects what kind of vision of TL this activity is enacting, but participants' lived experiences influence how teachers perceive their actual and expected roles in TL.

Table 2 maps how the observable operationalizations of TL-PD activities-connect to the five approaches, while Table 1 reflects the assumptions behind the conceptualizations. The typical PD activities (workshops, reflective journal writing) and typical vocabulary (teacher training, best practice, reflection) are encountered by teachers in their TL experiences, but the assumptions behind these activities and language choices may remain unnoticed. Metaphorically, Table 2 reflects the visible tip of the iceberg of TL, while Table 1 captures the invisible, but potentially more impactful, underwater iceberg, which, unless made visible and paid attention to, may cause a disaster. Therefore, the proposed, apparently structured elaboration of the conceptualizations of TL, together with the key assumptions they project on PD activities, were employed as an analytical lens for understanding PBLA teacher training as a TL experience.

The five approaches can be interpreted as an evolutionary continuum of practicing and theorizing TL. This continuum reflects a progression from a unidimensional understanding of TL as skill learning toward acknowledging its complexity embedded in multiple contextual factors (TL as a sociocultural activity of dialogic interaction). These five approaches may work in synergy, unless they are operationalized through PD activities with rigidly defined limits that would prevent potentially productive cross-pollination, as may be the case with PBLA as a prescriptive PD initiative.

\section{TL in PBLA: Combining Behavioural and Cognitive Approaches}

The data sources examined in this study-surveys, interview responses, and PBLA implementation guidelines-indicate reliance of PBLA PD, both in vision and implementation, on the first two conceptualizations-TL as skill learning, and TL as a cognitive process. 
The view of TL as a cognitive process may be traced in PBLA theory presented in the PD events. This theoretical knowledge was believed to facilitate the intense assessment material creation demand of PBLA. However, the expected outcome of the cognitive process was a skillful and PBLA-compliant application of the approved knowledge, rather than deeper understanding or cognitively demanding inquiry. Therefore, the second conceptualization of $T L$ as a cognitive process is submerged under the emphasis on skill acquisition, as the introduction of PBLA theory is expected to lead to the development of the predetermined skill set. However, teacher comments revealed that the behavioural and cognitive vision of TL are not adequately supported in PBLA PD: the skill acquisition expectation was not supported by sufficient practical modelling, and the translation of PBLA theory into practice proved to be overwhelming for many teachers.

While infrequent mentions of the other three perspectives are present in some PBLA materials, they found limited support in the empirical data. Consistent with the two dominant conceptualizations, teacher role is envisioned as knowledge receiving and skills acquisition from a source located outside of the domain of teacher practice. It was expected that individual teachers would gradually become skillful and efficient producers of multiple assessment artefacts. Teacher's role as knowledge receiver is also reflected in the structured hierarchy of knowledge holders and designated transmitters in the implementation process: teachers are at the bottom of the knowledge-receiving pyramid, with the experts at the funding ministries, CCLB, administrators, and Leads comprising the top-down chain with minimal opportunities for interaction. The discrepancy between the role assigned to teachers in PBLA and the teacher-envisioned role may be a key factor in the negative teacher response to PBLA.

Despite episodic mentions of reflection and collaboration in PBLA documents, the training was designed with limited room for truly dialogic interactions, while multiple nonnegotiable requirements were imposed. These requirements are identical for novice and expert teachers, even though novice teachers usually experience multiple challenges regardless of additional pressures (Faez \& Valeo, 2012). Understanding TL as a deeply personal construction may be traced in the way PBLA teacher training is distributed over a year or more, allowing time for individual teachers to advance their understandings and hone their skills. However, the acceptable milestones for increased personal understandings are predetermined in the form of a gradually growing skill set in PBLA implementation, rather than personally relevant heuristics. For example, all teachers were supposed to start with a self-assessment of PBLA readiness, and progress to introducing "needs assessments and elements of task-based planning and assessment" (IRCC, 2016, p. 3) within the same time frame. This way, the personalized nature of knowledge construction is overshadowed by the prescriptive plan for skill acquisition, which 
disregards teachers' varying starting points and individual pace of progression in learning how to implement PBLA.

Similarly to the third conceptualization, the fourth one-TL as personal reflection-appears to be present in the vision of PBLA teacher training, but rather through lip service than through meaningful opportunities to reflect. Teachers are encouraged to reflect through self-assessment of PBLA readiness about successes and challenges in implementing "classroom practice standards" (IRCC, 2016, p. 3). A reflection checklist is provided, and an "action plan" is to be submitted to the administrator (CCLB, 2017). Such a sequence of mandatory checklists and formal "action plans" is an attempt to presumably generate and document complex reflective and cognitive processes through behavioural routines.

Contrary to the current conceptualization of TL as a complex sociocultural activity, PBLA teacher training merged the behaviourist perspective of TL as skill learning with the understanding of $\mathrm{TL}$ as a cognitive process but did not incorporate the other three more current perspectives on TL, including $\mathrm{TL}$ as dialogic interaction. While some PD activities with such potential are mentioned in the implementation guide, limited empirical data on successful operationalizations of group discussions, team-teaching, demonstration lessons, or teacher collaboration were available. The two contrasting cases demonstrated the range of possibilities in enacting PBLA teacher training in practice. It is symptomatic that in the exemplary case, the leader purposefully sought to improve PBLA PD, which resulted in employing a respectful and interactive support mechanism-nonjudgemental team-teaching. On the contrary, the opposite case of abusive teacher evaluation practices claimed to be following PBLA requirements.

These two cases can be interpreted as two opposite ends on the continuum of collaboration, community of practice, dialogic interaction, or other concepts originating in sociocultural theory but not discussed in this article. In the success case, collaboration and dialogic interaction took place, even though they may not have had a dedicated time frame or activity slot, such as a PLC or a PD session. The dialogic interaction was fostered by the leader that realized the value of collective practice-embedded knowledge creation. This exceptional case emerged in response to the perceived need to find a more productive and practice-oriented way to support TL than the options presented in PBLA materials. The response reflects current understanding of TL as active mutual participation, negotiated and renegotiated by the agents. Unfortunately, affordances for such collaborative search and negotiation of context-sensitive solutions were not predesigned in PBLA PD.

On the contrary, in the teacher abuse case, persistent references were made to PBLA requirements, PBLA compliance, and funders' expectations, to justify the situation that was affecting teachers' confidence, health, selfesteem, joy of teaching, workplace atmosphere, and collegial relationships, while disregarding teachers' needs, struggles, understandings, personal and 
professional identities, and emotions. In addition to such practices raising ethical and legal concerns, the situation was problematic from the current perspectives on TL as a complex process precisely contingent upon workplace atmosphere and the affective responses of participating actors (Golombek, 2015; Swain, 2013). This case illustrated the behaviourist vision of learning as conditioning, the success rate of which could be improved by punishment for unsatisfactory performance. Such a view is beyond the continuum of the five perspectives, which suggests theoretical and practical unsustainability of PBLA as PD potentially relying on the historically and ethically obsolete view of learning as behaviourist conditioning.

\section{Conclusions and Implications}

I have summarized empirical findings relevant to illuminating the conceptualization and operationalization of TL in PBLA PD for LINC/ESL teachers in Canada. While it is customary to conclude research papers with calls for more research, I feel obliged to precede it with a call for response from policymakers. In light of the findings reported above, as well as previous research, suspending the mandatory PBLA implementation might be the most efficient step toward addressing the shortcomings and preserving the limited effectiveness of PBLA as a TL experience. Below, I outline some advantages of such an apparently radical solution that may seem like throwing out the baby with the bathwater. While acknowledging the best intentions of introducing PBLA as a teacher-training initiative, we have a duty to adequately respond to the unintended consequences that surfaced in the implementation process.

The findings raise serious questions about whether mandatory PBLA PD has benefitted the profession and the programs as originally envisioned and claimed in the official discourse. In addition to theoretical issues, the mandatory PBLA PD created multiple practical challenges, so making PBLA an optional tool would offer the following benefits:

1. an opportunity to realign the vision and operationalization of TL with current theories and practices;

2. a relief in cases where the impact of PBLA on teacher morale, teacher retention, and communities of practice has been negative;

3. a reinstatement of previously available, flexible options for TL in response to personally and contextually relevant needs;

4. financial savings from suspending a large-scale PD initiative that most participants found counterproductive, if not detrimental.

Most PD experiences described by participants present a bleak picture that conflicts with language teacher expectations of a TL opportunity in a 
Western democracy in the 21st century. PBLA PD lacks engaged interaction and relies on scripted skills development as a result of knowledge transmission. The simple removal of the pressure created by the mandatory-ness of the implementation protocol can provide immediate relief in the acute cases of repressive power imbalance, while preserving positive dynamics, wherever they are present. It would also restore the field for truly dialogic and nonjudgemental communities of practice to emerge. Such a step would align with the current understandings of language teaching as a complex process defying attempts to be captured by one-size-fits-all methodical approaches (Kumaravadivelu, 2006).

Suspending the mandatory PBLA implementation would also re-establish previously available space, time, and energy for the wide array of directions that individual teachers may need or wish to explore in their professional TL. Most important, relinquishing the pressure to follow "the assessment protocol" perceived as "a teaching method" (Callan, 2017) would allow teachers to pursue roles that they individually envision for themselves, whether it be a skillful acquirer of best practices, a creative builder of practical teacher knowledge, a reflective practitioner, or a teacher-researcher. Such freedom for individual teacher trajectories would eliminate the tensions arising from the pressure to conform to PBLA-required teacher roles. Effective teacher evaluation models, if necessary, may need to be designed separately from inservice TL initiatives. Translated into fiscal benefits, suspending mandatory PBLA implementation would result in savings from not providing extensive PBLA training to those teachers and Leads who leave the profession in response to the pressures. Teacher and Lead attrition necessitates significant investments into the search and training of new hires, whose induction and retention are challenging even without the additional demands. Finally, stopping the PBLA implementation train would allow all stakeholders to discuss and reflect on both intended and unintended outcomes of the national PD initiative.

This study is an initial step toward much-needed further examinations of PBLA as possibly the largest PD initiative of its kind in Canada. Limitations of this article can be considered and addressed in further research. First, the large data set requires further and deeper analysis that was not feasible within the scope of this article. The data themselves have their own limitations. Certain groups, such as funders and policymakers, were represented only through policy documents, with surveys and interviews unavailable, but potentially illuminating the rationales and assumptions that may not have been reflected in the published materials. Second, because the original data collection tools did not focus on PBLA teacher training, it is possible that they failed to elicit aspects of TL experiences that could have been relevant to the current analysis. Finally, further examinations of the impact of PBLA as a language assessment and learning tool are necessary. In-depth research 
is urgently needed to shed light on both the benefits and side effects of this large-scale reform effort.

I hope that policy and decision-makers continue to design and implement research-based initiatives that minimize possibilities for unproductive tensions, so that Canada maintains its "most comprehensive system of adult ESL training in the world" (Derwing, 2017, p. 83). In general, PBLA teacher training does not seem to be achieving the presumed goal of improving the system to the degree claimed in the official discourse. The word choices themselves, most of which I preserved throughout this article-teacher training, language training, workshop delivery, non-negotiable, acquire skills-reflect a limited understanding of TL, and need to be reviewed before meaningful adjustments to the vision of teacher training are possible. Such productive adjustments would need to start with realigning perspectives on teacher learning with current theories and practices, acknowledging the complexity of generating and supporting teacher knowledge, rather than attempting to enforce a one-size-fits-all authoritarian model of teacher PD. I am confident that significant adjustments are necessary and timely in the interest of all stakeholders across Canada-language learners, teachers, administrators, policymakers, and funders - and that suspending the mandatory PBLA implementation can be the most efficient first step to alleviating the current situation.

Note

1. I chose to replace the word "instructor" with "teacher" to reflect my understanding of language teaching and learning as agentive and selfdirected, versus providing and following instructions, as implied by the former.

\section{Acknowledgements}

1. Writing of this article was made possible by the Ontario Graduate Scholarship, awarded through the University of Toronto (2018-2019).

2. I would like to thank Jennifer Lynn Burton, Ontario Institute for Studies in Education, University of Toronto, for assistance with coding scheme review.

3. I am grateful to anonymous reviewers whose thoughtful comments were instrumental in improving this article.

\section{The Author}

Yuliya Desyatova is a PhD student in Languages and Literacies Education at the University of Toronto. She has taught LINC classes for 12 years and has mentored more than 80 TESL students. As a result, her current research on PBLA implementation explores theoretical and practical issues in language learning and teaching, as well as in teacher education. 


\section{References}

Borg, S., \& Sanchez, H. S. (Eds). (2015). International perspectives on teacher research. Hampshire, New York: Palgrave Macmillan.

Bushe, G. R., \& Marshak, R. J. (Eds.). (2015). Dialogic organization development: The theory and practice of transformational change. Oakland: Berrett-Koehler Publishers.

Callan, N. (2017, December 3). When in the history of \#ESL have teachers ever felt the need to sign a petition to stop a teaching method?! That's how strongly they feel \#PBLA is a mistake ... [Tweet]. Retrieved from https://twitter.com/esljigsaws/status/937338850547965953

CCLB (Centre for Canadian Language Benchmarks) E-learning Portal. (n.d.). Retrieved from https://learning.language.ca/

CCLB (2015). Handout 1.0: PBLA foundations and principles. Session outline. Retrieved from http://learning.language.ca/pluginfile.php/3534/mod_resource/content $/ 2 /$ Handout $\% 20$ 1.0\%20Session\%20Outline\%20PBLA\%20Foundations\%20and\%20Principles_2015.pdf

CCLB. (2017). PBLA practice review framework overview \& principles working draft. Retrieved from https://pblaepg.language.ca/wp-content/uploads/2017/06/PBLA-Practice-ReviewFramework-Working-DRAFT-May-16-2017.pdf

CCLB. (2017a). PBLA emerging practice guidelines. Retrieved from https://pblaepg.language. ca/toc/

CCLB. (2017b). PBLA emerging practice guidelines. Part A: PBLA background. Rationale for PBLA. Retrieved from http://pblaepg.language.ca/part-a-pbla-background/rationale-forpbla/

CCLB. (2017c). PBLA emerging practice guidelines. Part B: PBLA in the classroom. Portfolio contents. Retrieved from https://pblaepg.language.ca/part-b-pbla-in-my-classroom/portfolio-contents/

CCLB. (2017d). PBLA emerging practice guidelines. Part B: PBLA in the classroom. Planning for PBLA in my classroom. Retrieved from https://pblaepg.language.ca/part-b-pbla-in-myclassroom/planning-for-pbla-in-my-classroom/

CCLB. (2017e). PBLA emerging practice guidelines. Part C: PBLA programming and administration. Getting ready for PBLA in Our Program. Retrieved from http://pblaepg.language. ca/part-c-pbla-programming-and-administration/getting-ready-for-pbla-in-our-program/

CCLB. (2017f). PBLA emerging practice guidelines. Part C. PBLA roles and responsibilities. Retrieved from https://pblaepg.language.ca/part-c-pbla-programming-and-administration/ pbla-roles-and-responsibilities/

Cochran-Smith, M., \& Zeichner, K. (Eds.). (2005). Studying teacher education: The report of the AERA panel on research and teacher education. Mahwah, New Jersey: Lawrence Erlbaum Associates, Inc.

Crandall, J., \& Christison, M. (Eds.). (2016). Teacher education and professional development in TESOL. New York: Routledge.

Cross, R. (2010). Language teaching as sociocultural activity: Rethinking language teacher practice. The Modern Language Journal, 94(3), 434-452. Retrieved from http://www.jstor.org. myaccess.library.utoronto.ca/stable/40856177

Derwing, T. M. (2017). The ins and outs of ESL in Canada: How the past can inform the future. TESL Canada Journal, 34(2), 83-96. Retrieved from http://dx.doi.org/1018806/tesl.v34i2.1264

Drew, R., \& Mudzingwa, C. (2018). The Portfolio-Based Language Assessment model: Perceptions of adult immigrant English language learners. BC TEAL Journal 3(1): 1-21. Retrieved from ejournals.ok.ubc.ca/index.php/BCTJ/article/download/267/309

da Silva Iddings, A. C. (2018). Applying sociocultural theory to prepare teachers to work with culturally and linguistically diverse students and families. In J. P. Lantolf, M. E. Poehner, \& M. Swain (Eds.), The Routledge handbook of sociocultural theory and second language development (pp. 505-526). New York: Routledge. Retrieved from https://www.routledgehandbooks.com/ doi/10.4324/9781315624747-32 
Donato, R., \& Davin, K. J. (2018). History-in-person: Ontogenesis and the professional formation of language teachers. In J. P. Lantolf, M. E. Poehner, \& M. Swain (Eds.), The Routledge handbook of sociocultural theory and second language development (pp. 457-471). New York: Routledge. Retrieved from https://www.routledgehandbooks.com/doi/10.4324/9781315624747-29

Faez, F., \& Valeo, A. (2012). TESOL teacher education: Novice teachers' perceptions of their preparedness and efficacy in the classroom. TESOL Quarterly, 46(3), 450-471. doi:10.1002/tesq.37

Fox, J., \& Fraser, W. (2012). Report on the impact of the implementation of PBLA on LINC teachers and students from September to December 2011. Internal technical report submitted to Citizenship and Immigration Canada, the Government of Canada, January 2012.

Fox, J. (2014). Portfolio-Based Language Assessment (PBLA) in Canadian immigrant language training: Have we got it wrong? Contact, 40(2), 68-83. Retrieved from https://www.teslontario.org/uploads/publications/researchsymposium/ResearchSymposium2014.pdf

Freeman, D., \& Johnson, K. E. (1998). Reconceptualizing the knowledge-base of language teacher education. TESOL Quarterly, 32(3), 397-417. doi:10.2307/3588114

Freire, P. \& Macedo, D. P. (1995). A dialogue: Culture, language, and race. Harvard Educational Review, 65(3), 377-402. Retrieved from http://simplelink.library.utoronto.ca/url.cfm/490927

Freise, M. (Ed.). (2018). Inspired by Bakhtin: Dialogic methods in the humanities. Brighton, MA: Academic Studies Press.

Golombek, P. (2015). Redrawing the boundaries of language teacher cognition: Language teacher educators' emotion, cognition, and activity. The Modern Language Journal, 99(3), 470-484. Retrieved from: https://doi-org.myaccess.library.utoronto.ca/10.1111/modl.12236

Guilherme, A., \& Morgan, W. (2018). Philosophy, dialogue, and education. London: Routledge.

Hall, V. J. (2017). Exploring teacher-student interactions: Communities of practice, ecological learning systems - or something else? Journal of Further and Higher Education, 41(2), 120-132. doi:10.1080/0309877X.2015.1070395

Hall, J., Vitanova, G., \& Marchenkova, L. (Eds.). (2005). Dialogue with Bakhtin on second and foreign language learning. New York: Routledge.

Han, Z., \& Rast, R. (2014). First exposure to a second language: Learners' initial input processing. Cambridge: Cambridge University Press.

Hennessy, S. (2014). Bridging between research and practice: Supporting professional development through collaborative studies of classroom teaching with technology. Rotterdam, Boston, Taipei: Sense Publishers.

Hennissen, P., Beckers, H., \& Moerkerke, G. (2017). Linking practice to theory in teacher education: A growth in cognitive structures. Teaching and Teacher Education, 63, 314-325. Retrieved from https://doi.org/10.1016/j.tate.2017.01.008

Herrera, L., \& Drew, R. (2016). PBLA report. In Language regional meetings. Vancouver Island, North/ Interior, Metro Vancouver and Fraser Valley. October 2016. Summary report. AMSSA, pp. 16-18. Retrieved from http://www.amssa.org/wp-content/uploads/2015/05/Language-RegionalMeetings-Summary-Report.pdf

Holmes, T. (2015). PBLA: Moving toward sustainability. TESL Canada Journal, 32(9), 113-123. Retrieved from http://www.teslcanadajournal.ca/index.php/tesl/article/view/1220

Illeris, K. (2018). Contemporary theories of learning: Learning theorists ... in their own words. London, New York: Routledge.

IRCC (Immigration, Refugees and Citizenship Canada). (2016). Introduction to the implementation package for lead instructors. (Password-protected access).

Johnson, K. (2006). The sociocultural turn and its challenges for Second Language Teacher Education. TESOL Quarterly, 40(1), 235-257. doi:10.2307/40264518

Johnson, K. (2009). Second Language Teacher Education: A sociocultural perspective. New York, London: Routledge. Retrieved from https://ebookcentral-proquest-com.myaccess.library. utoronto.ca/lib/utoronto/detail.action?docID $=432798$

Johnson, K. E., \& Golombek, P. R. (2018). Making L2 teacher education matter through Vygotskian-inspired pedagogy and research. In J. P. Lantolf, M. E. Poehner, \& M. Swain 
(Eds.), The Routledge handbook of sociocultural theory and second language development (pp. 443-456). New York: Routledge. Retrieved from https://www.routledgehandbooks.com/ doi/10.4324/9781315624747-28

Johnston, B. (1994). Teacher education and the MA in ESL: The students' perspective. In D. Li, D. Mahoney \& J. C. Richards (Eds.), Exploring second language teacher development (pp. 131150). Hong Kong: City University of Hong Kong.

Kozulin, A. (2015). The impact of cognitive education training on teachers' cognitive performance. Journal of Cognitive Education and Psychology, 14(2), 252-262.

Kubanyiova, M. (2012). Teacher development in action: Understanding language teachers' conceptual change. Hampshire, NY: Palgrave Macmillan.

Kumaravadivelu, B. (2006). Understanding language teaching: From method to postmethod. Mahwah, NJ: Lawrence Earlbaum Associates.

Lachini, K. (2017). Stop PBLA for continuous intake and academic programs. Online petition to Minister of Immigration, Refugees and Citizenship Honourable Ahmed D. Hussen. Retrieved from https://www.change.org/p/ministry-of-immigration-and-refugees-stoppbla-for-continuous-intake-and-academic-programs

Lantolf, J. P., \& Poehner, M. E. (2014). Sociocultural theory and the pedagogical imperative in L2 education: Vygotskian praxis and the research/practice divide. New York and London: Routledge.

Lantolf, J. P., Poehner, M. E., \& Swain, M. (Eds.). (2018). The Routledge handbook of sociocultural theory and second language development. New York: Routledge. Retrieved from https://www. routledgehandbooks.com/doi/10.4324/9781315624747

Lee, J. J., Murphy, J., \& Baker, A. (2015). "Teachers are not empty vessels": A reception study of Freeman and Johnson's (1998) "Reconceptualization of the knowledge-base of second language teacher education." TESL Canada Journal, 33(1), 1-21. Retrieved from http:// teslcanadajournal.ca/index.php/tesl/article/view/1224/1044

Lefstein, A., \& Snell, J. (2014). Better than best practice: Developing teaching and learning through dialogue. London: Routledge.

Loughran, J. (2006). Developing a pedagogy of teacher education. London: Routledge.

Masson, M. M. (2018). A critical re-imagining of French-language teacher learning and professional identities (Doctoral dissertation). Retrieved from Dissertations \& Theses @ University of Toronto; ProQuest Dissertations \& Theses Global. (Accession No. 2081135457).

Merriam, S. B. (2002). Qualitative research in practice: Examples for discussion and analysis. San Francisco: Jossey-Bass.

Mohammadian Haghighi, F. (2016). Investigating teachers' perceptions of the usefulness of PortfolioBased Language Assessment (PBLA) in Language Instruction for Newcomers to Canada (LINC) programme (Master's thesis). Retrieved from https://open.library.ubc.ca/cIRcle/collections/ ubctheses/24/items/1.0340525

Morrissey, K. (2018, October 22). Limbo. [Blog post]. Retrieved from https://joyofesl.blogspot. $\mathrm{com} /$

Neville Rule, P. (2015). Dialogue and boundary learning. Rotterdam: Sense Publishers.

Pettis, J. (2015). Portfolio-Based Language Assessment (PBLA): Guide for teachers and programs. Ottawa. Centre for Canadian Language Benchmarks. Retrieved from http://www.language. ca/documents/PBLA_Guide_e-version_2015.pdf

Renfrew, A. (2015). Mikhail Bakhtin. London, New York: Routledge.

Richards, J. C., \& Farrell, T. S. C. (2005). Professional development for language teachers: Strategies for teacher learning. New York: Cambridge University Press.

Richards, J. (2008). Second language teacher education today. RELC Journal, 39(2), 158-177. doi:10.1177/0033688208092182

Ripley, D. (2012). Implementing Portfolio-Based Language Assessment in LINC programs: Benefits and challenges. TESL Canada Journal, 30(1), 69-86. Retrieved from https://files.eric. ed.gov/fulltext/EJ1001891.pdf 
Ripley, D. (2018). PBLA from the bottom up: LINC instructors share the benefits and challenges of portfolios. TEAL News. Winter 2018, 16-18. Retrieved from https://www.bcteal.org/wpcontent/uploads/2018/04/TEAL-News-Winter-2018-FINAL-2.pdf

Sarid, A. (2012). Systematic thinking on dialogical education. Educational Philosophy and Theory, 44(9), 926-941. doi:10.1111/j.1469-5812.2011.00757.x

Scarino, A. (2014). Learning as reciprocal, interpretive meaning-making: A view from collaborative research into the professional learning of teachers of languages. The Modern Language Journal, 98(1), 386-401. Retrieved from http://www.jstor.org.myaccess.library.utoronto.ca/ stable/43651767

Skidmore, D., \& Murakami, K. (Eds.). (2016). Dialogic pedagogy: The importance of dialogue in teaching and learning. North York, ON: Multilingual Matters.

Swain, M. (2013). The inseparability of cognition and emotion in second language learning. Language Teaching, 46(2), 195-207. doi:10.1017/S0261444811000486

Swain, M., \& Kinnear, P., \& Steinman, L. (2011). Sociocultural theory in second language education: An introduction through narratives. Toronto, ON: Multilingual Matters.

Turner, F., Brownhill, S., \& Wilson, E. (2017). The transfer of content knowledge in a cascade model of professional development. Teacher Development, 21(2), 175-191. doi:10.1080/13664 530.2016 .1205508

Valeo, A., \& Faez, F. (2013). Career development and professional attrition of novice ESL teachers of adults. TESL Canada Journal, 31(1), 1-19. Retrieved from http://www.teslcanadajournal.ca/ index.php/tesl/article/view/1164

Vanderveen, T. (2018). The nature and impact of Portfolio Based Language Assessment (PBLA). TESL Ontario Contact Magazine, 44(3), 5-11. Retrieved from http://contact.teslontario.org/ wp-content/uploads/2018/10/Vanderveen.pdf

VanPatten, B., \& Cadierno, T. (1993). Input processing and second language acquisition: A role for instruction. The Modern Language Journal, 77(1), 45-57. doi:10.2307/329557

Vásquez, C., \& Reppen, R. (2007). Transforming practice: Changing patterns of participation in post-observation meetings. Language Awareness, 16(3), 153-172. doi:10.2167/la454.0

Veresov, N., \& Mok, N. (2018). Understanding development through the Perezhivanie of learning. In J. P. Lantolf, M. E. Poehner, \& M. Swain (Eds.), The Routledge handbook of sociocultural theory and second language development (pp. 89-101). New York: Routledge. Retrieved from https://www.routledgehandbooks.com/doi/10.4324/9781315624747-6

\section{Appendix A}

\section{Survey questions related to PBLA teacher training as a TL experience (Teacher Survey)}

27. PBLA training was a valuable professional learning experience for me.

28. My PBLA training has provided me with sufficient practical examples of PBLA in action.

29. My PBLA training has provided me with sufficient theoretical understanding of PBLA.

30. My PBLA training has provided me with examples of research-based evidence supporting PBLA.

33. I appreciate the work of our Lead Teacher on training my colleagues and me in PBLA implementation.

34. Our PBLA Lead Teacher is able to answer my questions about PBLA implementation as they arise.

35. Our PBLA Lead Teacher finds the responsibility of being a Lead Teacher rewarding.

36. Our PBLA Lead Teacher is able to offer necessary assistance in PBLA implementation. 
37. With more experience, it is getting easier for me to create assessment tasks for my students.

38. I still find it difficult to create reliable CLB-based assessment instruments for my students.

41. PBLA implementation has increased the amount of time spent on productive teacher collaboration.

42. PBLA implementation has positively affected relationships between me and my colleagues.

43. PBLA implementation has positively affected relationships between me and my supervisor(s).

44. PBLA implementation has positively affected my self-image of a professional teacher.

Interview questions related to PBLA teacher training

How effective did you find the PBLA training offered to you by your Lead Teacher?

What was especially useful about the training? What would you have changed?

Note. PBLA = Portfolio-Based Language Assessment; $\mathrm{TL}=$ Teacher Learning. 